\title{
The Role of HR Managers: A Conceptual Framework
}

\author{
Bahare Ghalamkari ${ }^{1}$, Negar Mahmoodzadeh ${ }^{1}$, Nouredin Barati ${ }^{1}$, Aliyu Isah-Chikaji ${ }^{1}$, Ahmed Umar Alkali ${ }^{1}$ \& \\ Roya Anvari ${ }^{1}$ \\ ${ }^{1}$ Department of Human Resource Development, Faculty of Management, Universiti Teknologi Malaysia, \\ Malaysia \\ Correspondence: Roya Anvari, Department of Human Resource Development, Faculty of Management, \\ Universiti Teknologi Malaysia, Malaysia. E-mail: roya.anvari@utm.my
}

\author{
Received: September 2, 2014 Accepted: October 18, 2014 Online Published: April 2, 2015 \\ doi:10.5539/ass.v11n9p118 URL: http://dx.doi.org/10.5539/ass.v11n9p118
}

\begin{abstract}
In the process of decentralization, the role of Human Resource (HR) Manager has changed from having overall responsibility for employees to having responsibility for the management of the organization. Despite the aforementioned fact, a gap in the knowledge can be detected in the field of systematic evaluations of the claims that it is linked to effectiveness and doubts. This review has determined influence of HR practices on the three basic patterns base on Resource based view. Further studies need to be established to study other important factors involved.
\end{abstract}

Keywords: human resource management, performance, resource based view

\section{Introduction}

The factors of globalization of production and markets contribute to increase the dynamism of the competitive environment and innovation in global scale. Firms need to exploit all the available resources as a means of achieving competitive advantage in order to survive in a global economy in the new millennium. The human resources have been recently identified as a source of competitive advantage (Pfeffer, 1994). To state the matter differently, it is widely accepted that people in organizations are an important source of competitive advantage for firms. According to several researches, the assumptions that employees and the way they are managed are critical to the success of a firm are based on the increasing interest in human resources (Lado \& Wilson, 1994; Wright \& McMahan, 1994; Kamoche, 1996). Similarly other researchers consider human resources as intangible assets that have essential role for successful in organizations (Rayej et al., 2011). Several of the strategic human resource management studies have been concentrated on the understanding the relationship between SHRM practices and firm performance because firm performance is considered as one of the major organizational goals. As the matter of fact, it is rational to emphasize on the role of SHRM system as solutions to business problems in a study that illustrates the organizations with ability to achieve competitive advantages and greater market share. Producing the quality and productive individuals that will eventually minimize the problems that are related to human resource such as turnover of employees, job dissatisfaction and absenteeism are the direct results of having an effective strategic human resource. In order to compete effectively with other organizations, firms must constantly improve their performance by enhancing quality, reducing costs and differentiating their services and products. Furthermore, by increasing the intensity of competition among organizations, corporation cannot guarantee their ability to compete by price, quality competition and eventually uncertainty of environment increases. Hence, innovation and speed in respond to customers is the key to business success (Chang \& Huang, 2005).

The pressures on firm increase considerably and the need to continuously reform ways to compete has become inevitable. It was indicated that only by the value, rarity, difficult to copy and difficult to imitative a firm is able to achieve competitive advantage (Barney, 1991). According to many investigators, a sustained competitive advantage for an organization will be gained if that organization controls human resources in a direct employment relationship (Wright \& McMahan, 1994). Similarly, finding of Pang et al. (2009) in IC design industry in Taiwan shows that the management and human resources have positive impacts on firm performance.

The quality of being diverse and not comparable in kind of human resources makes investigators to seek competitive advantage from outside the enterprise environment, industry structure that transferred to the internal enterprise. Current research is an effort to analyse the human resource practices in the enterprise applications. 


\section{Strategic Human Resource Management}

Although, many various definitions of SHRM have been recognized over the past several years, the term remains unclear. SHRM has been described in various ways by investigators. They referred to SHRM as an outcome, a process or as a combination of process and outcome (Chang \& Huang, 2005). Strategic human resource management was defined by Wright and McMahan (1992) as a model that enables a firm to achieve its goals through the human resource. for human resource manager SHRM has been described by Ulrich and Lake (1991) as a process to link between business strategy and human resource practices. Some scholars considering both process and outcomes together and described SHRM as the correlation agent between the improvement of business performance and cultivation of an organizational culture and human resource functions with strategic goals and organizational objectives (Truss \& Gratton, 1994). Researchers have consensus toward the central feature of SHRM in the absence of a consistent definition which is included implementing and designing a set of internally consistent practices and policies to ensure that firm human capital contributes to achieving business objectives (Jackson \& Schuler, 1995; Hope-Hailey et al., 1999; Jackson \& Schuler, 1995; Hope-Hailey et al., 1999). The process to combine human resources with the organization's strategic objectives has been known as strategic human resource management (Bratton \& Gold, 2001). It is a novel field of study which combined of two different fields of research, strategic management and human resources management (Xiao-dong, 2004). A general definition of strategic human resource management that we can rely on is: a process that motivates, chooses, sustains and develops human resources in order to achieve organization's strategic objectives.

\section{Resource-Based View of the Firm}

The unique bundles of intangible and tangible assets that are valuable, imperfectly imitable, sustainable and rare referrers to the resource based view are the fundamental of firm competitiveness (Barney, 1991).The theory of resource based view of the firm in strategic human resource management has gained great deal of attention (Wright \& Snell, 1991; Virick et al., 1999). Human being is a significant part of an organization's resources based on RBV theory.

Therefore, organizations that manage to value this resource will get advantages in compare with their competitors which ultimately usher them to long term profitability (Barney, 1986; 1991). Organizations have the ability to apply human resource practices which lead them to develop strategies and eventually to a sustained competitive advantage (Schuler \& MacMillan, 1984; Ulrich \& Lake, 1991). Regarding to the potential of resources, resource of sustained competitive advantage has a recognizable quality such as inimitable, valuable, non-substitutable and rare (Barney, 1991).

\section{Human Resource Management and Performance}

The linkage among human resource management and organizational performance and also competitive advantages has been indicated by various researches (Jackson et al., 1997; Harel \& Tzafrir, 1999; Huang et al., 2008). It was shown by theoretical works on business strategy that firm human resources (HR) are able to generate firm competitive advantage. The firms could develop sustained competitive advantage through creating value according to the resource based view(Barney, 1986). These firms make it difficult and rare to intimate for their competitors. The value of it become clear when we realize that natural resources, technology and economics of scale which comprised traditional sources of competitive advantage are quite easy to imitate. Human resource's notion as a strategic asset involved many advantages for this issue. The value is created by an invisible asset entitle human resource. HR improves firm ability to deal with a turbulent environment. Hence, the fundamentals of strategic human resource management are to achieve competitive advantage and enhance business performance through Human resource management system. To state the matter differently, in order to develop and achieve organizational strategy's aims, it is compulsory to enhance the core competitive advantage of resources.

\section{Classification of SHRM Practices}

Although he classification of SHRM practices is a controversial issue, a comprehensive literature review on strategic human resource management theory was conducted by Delery and Doty (1996). They concluded that there are three dominant modes of theorizing which comprise of contingency, configurational and universalistic approach.

Universalistic perspective: The universalistic perspective has been described by several investigators and encourages as the best practice approach to SHRM. It has been referred as the selection of the right human resource practice which suits to best for organization (Huselid, 1995; Fitz-enz, 1997; Pfeffer \& Veiga, 1999; Truss, 2001).Based on the global perspective, in order to attain and sustain competitive advantage, a universal 
set of HRM best practices should be applied (Pfeffer, 1994; 1995; Pfeffer \& Veiga, 1999). There are various applications for universal best practices. Some of these applications have been declared by Delery and Doty's (1996) such as formal training systems, internal career ladders, and employment security, broadly defined jobs, results oriented appraisal, employee voice and performance based compensation.

Contingency approach: According to the contingency approach which is the second approach, superior performance will be reported in an organization that has HR policy and responsible toward external factors(Miles \& CC, 1978; Porter \& Millar, 1985; Guest, 1997). Based on the contingency theory, the relationship between the relevant dependent and independent variables will be differ for deferent level of critical continence variable. The primary contingency factor in the strategic HRM literature is the organization's strategy perspective suggests that the reorganizations should impalement human resource practices that promote employee behaviours in the frame of the organization's strategy. The organizations will be able to achieve superior performance by applying this alignment of strategy and HRM practices (Delery \& Doty, 1996). In order to exceed the only financial dimension of performance, contingency approach seeks to integrate other criteria like customer satisfaction, flexibility, social image, product quality or innovation (Arcand et al., 2003).

Configurational approach: The holistic principle of inquiry is used by configurational theories in order to recognize unique patterns of factors or configurations that are proposed to be maximally effective. As the matter of fact, nonlinear synergetic effects and higher order interactions are represented by such configurations (Delery \& Doty, 1996). A more comprehensive look at the configurations suggested that it likes an architecture of multiple (non-linear) and interactive bonds between the HRM bunches of practices and the strategy elements (Miller, 1989).Therefore, a system perspective is used by configurational approach and it is founded on the holistic pattern of HR practices. The contingency theory tries to find the correlation between organizational strategy and individual HR practices. The main debate in the configurational approach concentrates on pattern of relationships among human resource practices that anticipate superior performance when applied in association with one another or correct strategy or both (Delery \& Doty, 1996).

\section{Strategic Human Resource Management Practices in the Organization}

Human resources management engaged in upgrading human resources of enterprises despite the fact that practices are complex and complicate. Several scholars concentrated on the examination of the adoption of HR practices based on the significant growing of HR practices and its effect on the competitive advantage (Tannenbaum \& Dupuree-Bruno, 1994). Also, other aspects of HR practices have been considered such as financial performance and effects on organizational outcomes, such as productivity and efficiency (MacDuffie, 1995; Delery \& Doty, 1996; Snell et al., 1996; Pfeffer, 1998; Collins \& Clark, 2003) four categories of practice have been identified by several empirical studies of human resource practices and organizational performance and its positive effects on organizational performance has been acknowledged.

\section{Training and Development}

Training regarded as a vital expenditure to make the organization more effective and also it has effect on increasing productivity in an organization. Practising a systematic modification of behaviour through learning events, programmers and instruction has been described by Armstrong (2001). This training enables the individuals to achieve the levels of skill, knowledge and competence required to perform their work effectively. Maximum productivity that is achieving by effective and efficient employee's performance is more related to training of manpower as the main initial needs for every organization. In fact, employees will have better performance when they obtain initial ability, knowledge and skill trough the training program (Akinyele, 2007). To state the matter differently, SHRM researchers show human resource management practices that affect behaviour of individuals which ultimately influence organization as well as its employee in a positive manner (Guest, 1987; Iles, 1990; Becker \& Gerhart, 1996; Jackson et al., 1997; Meyer, 1997). Goldstein (1980) and Latham (1988) in Clarke (2010, p. 11), defined training as "The systematic acquisition and development of the knowledge, skills, and attitudes required by employees to adequately perform a task or job or to improve performance in the job environment". The demand for the organization to accelerate the renewal of knowledge is become vital regarding the speed of technological upgrade, the process of globalization and customer demands. Based on this perspective, the main focus in the training for a specific job is to enhance staff quality, organizational adaptability, diversity and overall organizational skills training, innovation and eventually potential to absorb high level dynamic capabilities.

\section{Performance Appraisal}

In context of performance appraisal by providing feedback to support the attainment of strategic goals and monitoring performance the assimilation stage is facilitated (Werbel \& DeMarie, 2005). Based on Some scholars 
performance appraisal is intended to further formalize the process of employee's controlling also it can be consideration as implement in management (Brown \& Heywood, 2005). According to Hsu et al. (2011) in order to establish the performance evaluation standardise, supervisors have perceived human resource has become more significant in business. Performance appraisals can be motivate employees for significant contribution attempts by appropriately manage and strategy for changing and developing behaviours with reasonable aims, providing positive feedback, and appraisal evaluate performance (Hester, 2005). These employees adopt behaviours that are monitored for performance appraisals regarding this assumption that they wish to have positive performance evaluations. Furthermore, in order to reinforce desired behaviours and skills plus offer constructive criticisms, performance appraisal feedback is designed. Also, to monitor employee performance, the traditional control based human resource management practices have been used. It accentuates on the employee evaluation and their results, which are according to the perspective of ex post facto control evaluation of the work of employees. The following points are presented despite the fact that the four strategic human resource practices influence the organization performance.

\section{Employee Behaviour}

The concept of motivated employees are likely to perform better and ultimately leading to higher firm performance is the basic of the Ability, Motivation and Opportunity (AMO) theory (Paauwe \& Boselie, 2005). In order to exhibit favourable attitudes and behaviours, which are necessary for supporting the competitive strategy of an organization, HRM practices play an significant role in motivating employees (Hiltrop, 1996; Anvari \& Atiyaye, 2014). There are several applications for SHRM practice, such as improving the ability of staff to execute their responsibilities, inspiring staff's motivation, creating opportunity for employee to participate in the organizational objectives. Through the staff behaviour towards the direction of the enterprise recognized norms the organizational performance as well as employee performance will be improved. It is only increase the cost of enterprise management and possessing a high turnover rate whether creating a rigorous selection of training for employee do not associate with complement and appreciation.

\section{Dynamic Match}

In order to have more efficiency impact on organizational performance, initially SHRM require matching with organizational strategy. Also, there must be mutual complementary and support among the various HR practices. Based on several empirical studies, the certain types of organizational performance such as employee participation and profit sharing will be enhanced through various human resource practices. Thus, different combinations and systematic practice of human resources must be applied in order to improve the firm. The companies required to apply the selection methods of internal promotion when the external labour market is tense. Regarding the appropriate intake of personnel for a company it is possible to recruit from the outside.

\section{Contingency Aspects}

The influence of the strategic human resource management practices on the business strategy is indicated through the strategic human resource management. Several of other contingency factors such as firm size, organizational culture have a significant impact on strategic human resource practices.

As the matter of fact, there is a difference between the performance assessment methods and manufacturing industry. A formal and comprehensive range of human resource management usually is preferable for the large companies. However, the companies that are in early stage of growth concentrated on absorbing talents while the growth stage companies tend to institutionalize and standardize their process. A full consideration of organization's internal and external environment is required to select the suitable and practical strategic human resource management practice. Regarding the better firm performance and being the sources of sustained competitive advantage theoretical research on SHRM proposed that systems of HR practices are a reliable source It is because that these systems of practices are often unique, multifaceted and difficult to imitate (Lado \& Wilson, 1994). Despite the fact that HR practices are able to be a source of sustained competitive advantage, they only support competencies that provide value to a firm (Gardner et al., 2003).

\section{References}

Akinyele, S. (2007). The impact od Nigeiea trainig perogran on employee's perforamnce. Business Management, 1(1), 11-19.

Allani, N., \& Arcand M. (2003). Impact of Strategic Human Resources Management on Innovation. 12th International Conference on Management of Technology: IAMOT, Nancy - France.

Anvari, R., \& Atiyaye, D. M. (2014). Determinants of effective communication among undergraduate students. International Education Studies, 7(9), 112-121. http://dx.doi.org/10.5539/ies.v7n9p112 
Armstrong, M. (2001). A Handbook of Management Techniques: The Best Selling Guide to Modern Management Method. Kogan Page Ltd.

Barney, J. (1986). Strategic factor markets: expectations, luck, and business strategy. Management Science, 32(10), 1231-1241. http://dx.doi.org/10.1287/mnsc.32.10.1231

Barney, J. (1991). Firm resources and sustained competitive advantage. Journal of Management, 17(1), 99-120. http://dx.doi.org/10.1177/014920639101700108

Becker, B., \& Gerhart, B. (1996). The impact of human resource management on organizational performance: Progress and prospects. Academy of Management Journal of East-West Business, 1(39), 779-801.

Bratton, J., \& Gold, J. (2001). Human resource management: theory and practice. Psychology Press.

Brown, M., \& Heywood, J. S. (2005). Performance appraisal systems: determinants and change. British Journal of Industrial Relations, 43, 659-679. http://dx.doi.org/10.1111/j.1467-8543.2005.00478.x

Chang, W., \& Huang, T. (2005). Relationship between strategic human resource management and firm performance: A contingency perspective. International Journal of Manpower, 26(5), 434-449. http://dx.doi.org/10.1108/01437720510615125

Chow, I., \& Huang, J. (2008). Strategic HRM in China: Configurations and competitive advantage. Human Resource Management, 47(4), 687-706. http://dx.doi.org/10.1002/hrm.20240

Clarke, N. (2010). Exploring the training-quality of care link in adult social care: challenges from an HRD perspective. Review of Public Personnel Administration.

Collins, C., \& Clark, K. (2003). Strategic human resource practices, top management team social networks, and firm performance: The role of human resource practices in creating organizational competitive advantage. The Academy of Management Journal, 46(6), 740-751. http://dx.doi.org/10.2307/30040665

Delery, J., \& Doty, D. (1996). Modes of theorizing in strategic human resource management: Tests of universalistic, contingency, and configurational performance predictions. Academy of Management JournaL, 39(4), 802-835. http://dx.doi.org/10.2307/256713

Feng, Y.-Y., \& pan W.-H. (2009). The effect of firms resources and capabiliites on its perforamnce of IC desogne industry in Taiwan. Inforamtion Technology Journal, 8(5), 668-697.

Fitz-enz, J. (1997). The truth about best practices: What they are and how to apply them. Human Resource Management, 36(1), 97-103. http://dx.doi.org/10.1002/(SICI)1099-050X(199721)36:1<97::AID-HRM16>3. $0 . \mathrm{CO} ; 2-\mathrm{B}$

Goldstein, I. L. (1980). Training in work organizations. Annual Review of Psychology, 31, 229-272. http://dx.doi.org/10.1146/annurev.ps.31.020180.001305

Gratton, L., \& Hope-Hailey, V. (1999). Linking individual performance to business strategy: The people process model. Human Resource Management, 38(1), 17-31.

Guest, D. E. (1997). Human Resource Management and Performance: A Review and Research. Agenda. International Journal of Human Resource Management, 8(3), 263-276. http://dx.doi.org/10.1080/ 095851997341630

Guest, D. H. J. (1987). Human Resource Management and Industrial Relations. Journal of Management Studies, 24, 503-521. http://dx.doi.org/10.1111/j.1467-6486.1987.tb00460.x

Harel, G., \& Tzafrir, S. (1999). The Effect of Human Resource Management Practices on the Perceptions of Organizational and Market Performance of the Firm. Human Resource Management, 38(3), 185-199.

Hester, L. j. (2005). The impact of strategic human Resource management on Organizational performance: A perspective of the resource based view of the firm.

Hiltrop, J. M. (1996). The impact of human resource management on organisational performance: theory and research. European Management Journal, 14(6), 628-637.

Huang, Y. f., \& Hsu K.-H. (2011). Discussing perforamnce indec of human resouce valuation with AHP_Occupational safety section in T company in taiwan as teh case study. Informantion tehcnology Journal, 10(3), 549-556.

Huselid, M. (1995). The impact of human resource management practices on turnover, productivity, and corporate financial performance. Academy of Management Journal, 38(3), 635-672. 
http://dx.doi.org/10.2307/256741

Huselid, M., \& Jackson S. (1997). Technical and strategic human resource management effectiveness as determinants of firm performance. Academy of Management Journal, 171-188.

Iles, P., Mabey, C., \& Robertson, I. (1990). RM Practices and Employee Commitment: Possibilities, Pitfalls and Paradoxes. British Journal of Management, 1(3), 147-157. http://dx.doi.org/10.1111/j.1467-8551.1990. tb00003.x

Jackson, S., \& Schuler, R. (1995). Understanding human resource management in the context of organizations and their environments. Annual review of psychology, 46. http://dx.doi.org/10.1146/annurev.ps.46.020195. 001321

Javadein, S. r. S., \& Rayej, H. (2011). The role of internal marketin in creation of sustainable competitie advantages. Trends in Apllied Sciences Reearch, 6(4), 364-374.

Kamoche, K. (1996). The integration-differentiation puzzle: a resource-capability perspective in international human resource management. International Journal of Human Resource Management, 7(1), 230-244. http://dx.doi.org/10.1080/09585199600000126

Lado, A., \& Wilson, M. (1994). Human resource systems and sustained competitive advantage: A competency-based perspective. Academy of Management Review, 19(4), 699-727.

Latham, G. P. (1988). Human resources training and development. Annual Review of Psychology, 39, 545-582. http://dx.doi.org/10.1146/annurev.ps.39.020188.002553

MacDuffie, J. (1995). Human resource bundles and manufacturing performance: Organizational logic and flexible production systems in the world auto industry. Industrial \& Labor Relations Review, 48(2), 197-221. http://dx.doi.org/10.2307/2524483

McMahan, G., \& Virick, M. (1999). Alternative theoretical perspectives for strategic human resource management revisited: Progress, problems, and prospects. Research in personnel and human resource management, 4, 99-122.

Meyer, J. P., \& Allen, N. J. (1997). Commitment in the Workplace: Theory, Research, and Application Thousand Oaks. CA: Sage.

Miles, R. E., \& CC, S. (1978). Organizational Strategy, Structure, and Process. McGraw-Hill: New York.

Miller, P. (1989). Strategic human resource management: what it is and what it isn't. Personnel Management, 10, 46-51.

Paauwe, J., \& Boselie, J. P. (2005). HRM and performance: What's next?

Pfeffer, J. (1994). Managing with power: Politics and influence in organizations. Harvard Business Press.

Pfeffer, J. (1995). Mortality, reproducibility, and the persistence of styles of theory. Organization Science, 681-686. http://dx.doi.org/10.1287/orsc.6.6.681

Pfeffer, J. (1998). The human equation. Cambridge/Mass.

Pfeffer, J., \& Veiga, J. (1999). Putting people first for organizational success. The Academy of Management Executive (1993-2005), 13(2), 37-48.

Porter, M. E., \& Millar, V. E. (1985). How information gives you competitive advantage. Harvard Business Review, 63(4), 149-160.

Schuler, R. S., \& MacMillan, I. C. (1984). Gaining competitive advantage through human resource management practices. Human Resource Management, 23(3), 241-255. http://dx.doi.org/10.1002/hrm.3930230304

Tannenbaum, S., \& Dupuree-Bruno, L. (1994). The relationship between organizational and environmental factors and the use of innovative human resource practices. Group and Organization Management, 19(2), 171-202. http://dx.doi.org/10.1177/1059601194192005

Truss, C. (2001). Complexities and Controversies In Linking HRM With Organizational Outcomes. Journal of Management Studies, 38(8), 1121-1149. http://dx.doi.org/10.1111/1467-6486.00275

Truss, C., \& Gratton, L. (1994). Strategic human resource management: A conceptual approach. The International Journal of Human Resource Management, 5(3), 663-686.

Ulrich, D., \& Lake, D. (1991). Organizational capability: creating competitive advantage. The Executive, 5(1), 77-92. http://dx.doi.org/10.5465/AME.1991.4274728 
Werbel, J., \& DeMarie, S. (2005). Aligning strategic human resource management and person-environment fit. Human Resource Management Review, 15(4), 247-262. http://dx.doi.org/10.1016/j.hrmr.2005.10.001

Wright, P., \& Gardner, T. (2003). The impact of HR practices on the performance of business units. Human Resource Management Journal, 13(3), 21-36. http://dx.doi.org/10.1111/j.1748-8583.2003.tb00096.x

Wright, P., \& McMahan, G. (1992). Theoretical perspectives for strategic human resource management. Journal of Management, 18(2), 295. http://dx.doi.org/10.1177/014920639201800205

Wright, P., \& McMahan, G. (1994). Human resources and sustained competitive advantage: a resource-based perspective. The International Journal of Human Resource Management, 5(2), 301-326.

Wright, P., \& Snell, S. (1991). Toward an integrative view of strategic human resource management. Human Resource Management Review, 1(3), 203-225. http://dx.doi.org/10.1016/1053-4822(91)90015-5

Xiao-dong, Y. (2004). Enhancing university students' creativity: reflection and suggestions. Journal of Higher Education, 1 .

Youndt, M., \& Snell, S. (1996). Human resource management, manufacturing strategy, and firm performance. Academy of Management Journal, 39(4), 836-866. http://dx.doi.org/10.2307/256714

\section{Copyrights}

Copyright for this article is retained by the author(s), with first publication rights granted to the journal.

This is an open-access article distributed under the terms and conditions of the Creative Commons Attribution license (http://creativecommons.org/licenses/by/3.0/). 